\title{
A New Method of Calculating Copyright Liability for Cable Rebroadcasting of Distant Television Signals
}

\author{
Since its inception in 1949,1 America's cable television industry (cable) \\ has been molded by governmental regulation ${ }^{2}$ designed to maximize both \\ the diversity ${ }^{3}$ and efficiency ${ }^{4}$ of programming available to television view- \\ ers. ${ }^{8}$ The cable television provisions of the 1976 Copyright Act (the Act), ${ }^{6}$
}

1. The first cable television station began operation in Astoria, Oregon in 1949. Besen \& Crandall, The Deregulation of Cable Television, 44 Law \& ConteMP. ProBs. 77, 81 (1981).

2. The Federal Communications Commission (hereinafter FCC) regulates cable as an industry "reasonably ancillary" to broadcasting. United States v. Midwest Video Corp., 406 U.S. 649, 659-70 (1972) (plurality opinion); United States v. Southwestern Cable Co., 392 U.S. 157, 167-78 (1968). Congressional power to regulate cable comes from the commerce clause, U.S. CoNST. art. I, $\S 8$, cl. 3, and from Congress' mandate "To promote the Progress of Science and useful Arts, by securing for limited Times to Authors and Inventors the exclusive Right to their respective Writings and Discoveries." U.S. ConsT., art. I, § 8, cl. 8. See H.R. Rep. No. 94-1476, 94th Cong., 2d Sess. 47 (1976), reprinted in 1976 U.S. CODE CoNG. \& AD. NEws 5659 [hereinafter cited as House Copyright Report].

3. See FCC v. National Gitizens Comm. for Broadcasting, 436 U.S. 775, 796-97 (1978); United States v. Midwest Video Corp., 406 U.S. 649, 665-669 (1972) (plurality opinion); Malrite T.V. of N.Y. v. FCC, 652 F.2d 1140, 1151 (2d Cir. 1981); In the Matter of Cable Television Syndicated Program Exclusivity Rules, 71 F.C.C.2d 951, 955 (1979) (FCC goal is to promote "the maximum range of diversity and choice available to the public"); Hatfield \& Garrett, A Reexamination of Cable Television's Compulsory Licensing Royalty Rates: The Copyright Royalty Tribunal and the Marketplace, 30 J. Copyright Soc'y of U.S.A. 433, 472-73 (1983); see also Goodale, Big Picture Before the 2nd Circuit: Whether to Deregulate Cable TV, 3 NAT'L L.J., Dec. 8, 1980, at 29 ("[T]he Supreme Court, Congress and the FCC have desired above all to facilitate diversity in programming.").

The term diversity includes both an increase in the number of programs available per hour as well as an increase in the number of new programs being produced. The proposals contained in this Note will both ensure the optimal availability of existing television programs to cable viewers and maximize the production of new television programs. See infra note 56 .

4. See Communications Act of 1934, § 1, 47 U.S.C. $\S 151$ (1982) (the FCC is established "so as to make available .. . a rapid, efficient . . communications service"); Inquiry Into the Economic Relationship Between Television Broadcasting and Cable Television, 71 F.C.C.2d 632, 661 (1979); In the Matter of Amendment of Part 76 of the Commission's Rules and Regulations Relative to an Inquiry on the Need for Additional Rules in the Area of Duplicative and Excessive Over-Regulation of Cable Television," 54 F.C.C.2d 855, 890-91 (1975) (identifying "[our] Congressionally-mandated goal of developing an efficient nationwide and worldwide communications system" as a primary goal of FCC regulation of cable television) (emphasis in the original).

The production or distribution of goods in a market is efficient if the cost of the production or distribution of the last unit of the good delivered (marginal cost) equals the marginal revenue derived from that unit's sale. In a competitive market, this amount equals the good's market price. The existence of an efficient price and an efficient level of production or distribution of the good ensures that both the consumer public and product producers derive maximum value from the production and distribution of the good. See R. Lipsey, P. Steiner \& D. Purvis, Economics 231-32 (7th ed. 1984); P. Samueison, Economics 433-36 (11th ed. 1980); P. WonnacotT \& R. WonnacotT, Economics 493-98 (2d ed. 1982). Efficiency in the availability of television programming thus requires that for each rebroadcast copyright owners receive royalties that reflect the marginal value of the programming to consumers. Besen, Manning \& Mitchell, Copyright Liability for Cable Television: Compulsory Licensing and the Coase Theorem, 21 J. L. \& EcoN. 67, 68, 83 (1978).

5. This has frequently meant benefiting either cable or broadcast television at the other industry's 
however, frustrate these goals of enhanced diversity and efficiency. The Act, which regulates the cable industry's ability to rebroadcast distant television signals to cable subscribers, ${ }^{7}$ subsidizes cable by granting it the right to rebroadcast copyrighted television programs for statutory royalty fees that are far less than market copyright rates. This subsidy is economically inefficient and limits program diversity by reducing the value of syndicated television programs and thus discouraging the production of new programs, and by eliminating cable's incentive to produce or commission its own programs for use on cable.

Using basic economic theory and the Coase Theorem, ${ }^{8}$ this Note argues that negotiated adjustments between cable operators and copyright owners of the statutory copyright rates currently governing cable will lead to maximal program diversity and efficiency in the production of television programs. This Note shows how the current copyright law inhibits these adjustments, yet the Note rejects deregulation as an unworkable method of achieving negotiated royalty rates in light of hostility between television broadcasters and the cable industry. The Note therefore proposes a new, program-by-program royalty rate that would facilitate negotiated adjustments of cable royalties and avoid the problems of either deregulation or the current copyright law. Royalties under the new system would be paid directly from cable operators to copyright owners, thus eliminating the need for the inefficient and costly copyright enforcement machinery that Congress created as part of the 1976 Copyright Act.

\section{Copyright Liability Under the Act}

\section{A. The Current System}

The 1976 Copyright Act guarantees cable the right to intercept television signals from outside a local viewing area and to retransmit those signals to their cable subscribers upon payment of a statutory copyright fee. ${ }^{\ominus}$ In practice, this means cable will rebroadcast only distant independent stations since the rebroadcast of distant network stations would not be val-

expense. See Rivkin, The Changing Signals of Cable T.V., 60 Geo. L.J. 1475, 1481 (1972) ("Since 1968, the FCC has wrestled with the question of the extent to which it might enable limited distant signal importations to sustain cable growth without causing undue harm to broadcasters."); Chazen \& Ross, Federal Regulation of Cable Television: The Visible Hand, 83 Harv. L. REv. 1820, 1825 (1970).

Achievement of an optimally efficient level of syndicated programming will also result in maximum program diversity and vice versa. See infra note 56.

6. General Revision of Copyright Law Act of 1976, Pub. L. No. 94-553, 90 Stat. 2541 (codified at 17 U.S.C. $\S \S 101-810$ (1982)) (effective Jan. 1, 1978).

7. 17 U.S.C. $\$ \S 111,510,801-810$ (1982). Distant signals are those of distant stations which cannot be received over the air in the local service area of the cable station. Id. $\S 111(\mathrm{f})$.

8. Coase, The Problem of Social Cost, 3 J.L. \& Econ. 1 (1960).

9. 17 U.S.C. § 111. 
uable to cable subscribers. ${ }^{10}$ The Act assesses cable's royalty payments for such rebroadcasting per distant signal rather than per program. Thus, if a cable station rebroadcasts one program off a distant signal, it must pay a full half year's copyright royalty for the entire signal, even if the cable station never rebroadcasts another program from that signal. ${ }^{11}$

Independent television station operators purchase the right to show syndicated television programs through direct negotiations with program copyright owners. ${ }^{12}$ Yet, the copyright royalties these independent stations pay to rebroadcast syndicated programs are substantially higher than the statutory copyright rates cable stations in the same markets pay to rebroadcast these same programs off distant television stations. ${ }^{13}$ In practice, then, the Act serves to subsidize cable rebroadcasting of syndicated television programs by allowing cable stations to pay copyright owners less than market value for rebroadcasting copyrighted programs.

Under the provisions of the Act, cable stations pay copyright royalties for distant signal rebroadcasting which are calculated as a percentage of

10. Network stations across the country simultaneously broadcast identical programming during the vast majority of the broadcast day. Distant networks are thus of little value in markets that already receive all three networks over the air. Also, since network advertisers pay to reach a national audience, rather than a locally targeted one, cable's rebroadcast of network programs would aid rather than injure network broadcasters. Similarly, carriage of local signals on cable does not injure local broadcasters because advertisers on local stations benefit from and are willing to pay for additional exposure in the local market. See House Copyright Report, supra note 2, at 90, 1976 U.S. CodE Cong. \& AD. News 5659, 5704; Note, Cable Television's Compulsory License: An Idea Whose Time Has Passed?, 25 N.Y.L. ScH. L. REv. 925, 941-42 (1980). Compare infra text accompanying notes 22-27 regarding the losses due to rebroadcast of distant signals. Because neither network nor local rebroadcasting causes the damage to broadcasters, and through them to copyright owners, which is the subject of this Note, rebroadcasting of local and network stations will not be considered further.

11. 17 U.S.C. $\$ 111$ (d), (f). Such treatment is necessary because the 1976 Copyright Act makes no provisions for assessing copyright liability on a per-program basis. The new system proposed in Part II of this Note will facilitate rebroadcast of select portions of distant signals. This will allow cable to tailor its rebroadcasting more closely to the interests of its audience.

Substitution of programs from one distant signal to another is also statutorily prohibited under 17 U.S.C. $\S 111(\mathrm{c})(3)$. The House Judiciary Committee felt that substitution by cable of programs on distant signals made cable's function "similar to that of a broadcaster" and thus not entitled to the preferential copyright rates contained in the bill. House Copyright Report, supra note 2, at 93, 1976 U.S. Code Cong. \& AD. NEwS at 5708. This Note's proposal, however, will force cable to pay market rates to copyright owners. Furthermore, copyright liability under this proposal could be calculated and assessed for such substituted programming. Section 111(c)(3)'s prohibition of program substitution would thus no longer be necessary and could be properly repealed, although some limitation on cable's substitution of programming may be desirable. See infra note 55.

12. See, e.g., R. Nol., M. Peck \& J. McGowan, Economic Aspects of Television ReguLation 69-70 (1973); B. OWen, J. Beebe \& W. Manning, Tel.evision Economics 31-35 (1974); Besen, Manning \& Mitchell, supra note 4, at 77; Greene, The Cable Television Provisions of the Revised Copyright Act, 27 CATH. L. Rev. 263, 265-66 (1978); Note, Crossed Signals: Copyright Liability for Resale Carriers of Television Broadcasts, 16 IND. L. REv. 611, 613-14 (1983).

13. Besen, Manning \& Mitchell, supra note 4, at 88-90 (quantifying differential as well as surveying literature on value of distant signal importation); see Botein, The New Copyright Act and Cable Television-A Signal of Change, 24 BuLL. Copyright Soc'y USA 1, 14-16 (1976); Note, The Collapse of Consensus: Effects of the Deregulation of Cable Television, 81 Colum. L. REv. 612, 621-22 (1981). 
each cable system's basic subscription revenues. ${ }^{14}$ The copyright rates, many of which are less than $1 \%$ of cable subscription revenues per distant signal, ${ }^{15}$ are paid to a statutorily-created supervisory body, the Copyright Royalty Tribunal (GRT), which is empowered to distribute accumulated copyright royalties to program suppliers as well as to adjust the copyright royalty rates to reflect inflation and changes in the cable industry. ${ }^{16}$

In practice, however, the CRT lumps cable's semi-annual royalty payments into a single fund and then divides the entire pool into large chunks among the competing industry groups that represent the various types of programs that appear on cable television. ${ }^{17}$ These industry groups then divide up their shares, less the group's administrative costs, among their members in accordance with the group's own criteria. ${ }^{18}$ The result is that a copyright owner's royalties for a given year, much less for a given program or market, defy any type of prediction or even ex post calculation. Division of each year's copyright royalties itself takes three to five years to complete, ${ }^{19}$ at substantial administrative and legal cost to the affected industry. ${ }^{20}$

\section{B. Economic Inefficiency}

Cable's revenue from distant signal rebroadcasting comes from the additional subscription fees cable subscribers are willing to pay for the op-

14. 17 U.S.C. $\S 111(c)-(d)$.

15. The copyright rates are $0.799 \%$ of gross station receipts for the first distant signal equivalent rebroadcast, $0.503 \%$ for each of the second, third, and and fourth distant signal equivalents rebroadcast, and $0.237 \%$ for the fifth and each additional signal equivalent rebroadcast thereafter. 17 U.S.C. $\S 111$ (d)(2)(B). Royalty rates for some signals may go as high as $3.5 \%$ of a cable station's gross receipts, depending on a variety of other factors. 37 C.F.R. $\$ 308.2$ (1984).

16. 17 U.S.C. $\$ \S 801,804$. The law provides, however, that such adjustment shall ordinarily occur only once every five years.

17. See Christian Broadcasting Network v. CRT, 720 F.2d at 1300-01; National Ass'n of Broadcasters v. CRT, 675 F.2d at 371-72.

18. See Christian Broadcasting Network v. CRT, 720 F.2d 1295, 1308 (D.C. Cir. 1983); National Ass'n of Broadcasters v. CRT, 675 F.2d 367, 372 (D.C. Cir. 1982).

19. The distribution of the 1978 royalties and its attendant litigation was completed in April 1982. National Ass'n of Broadcasters v. CRT, 675 F.2d 367 (D.C. Cir. 1982). Portions of the 1979 distribution were overturned after an October 1983 ruling of the D.C. Circuit Court of Appeals (Christian Broadcasting Network v. CRT, 720 F.2d 1295 (D.C. Cir. 1983)). The CRT handed down a revised award on May 11, 1984 (49 Fed. Reg. 20048) and further litigation on the revised award is currently pending. Telephone interview with Fritz Attaway, General Counsel, Motion Picture Association of America (MPAA), March 28, 1985.

20. In fiscal year 1984 , the CRT cost $\$ 650,000$ to operate, of which $\$ 170,000$ was made up from royalties paid into the royalty fund. Copyright Office/Copyright Royalty Tribunal: Hearing before the Subcomm. on Courts, Civil Liberties, and the Administration of Justice of the House Committee on the Judiciary, 98th Cong., 1st Sess., at 91 (1983) (statement of Edward "Eddie" Ray, Chairman, CRT); Fiscal Year 1984 Budget of THE UNITEd STATES 8-13. The participants' cost of litigating the distribution of the $\$ 15$ million in royalties collected in 1978 before the GRT and the courts was estimated by the major participant to be $\$ 5$ million. Oversight of the Copyright Act of 1976: Hearings before the Senate Comm. on the Judiciary, 97th Cong., 1st Sess. 201 (1981) (statement of Jack Valenti, President, MPAA) [hereinafter cited as 1981 Senate Hearings]. 
portunity to see the programs on each distant signal. ${ }^{21}$ Cable derives no advertising revenue from distant signal rebroadcasting, since the great majority of advertising on independent television stations is locally targeted and thus has no value in a distant market. ${ }^{22}$ Substitution of local advertising for that of the distant signal is not currently permitted by law. ${ }^{23}$

The cost to copyright owners of cable's distant signal rebroadcasting is a reduction in the income they receive for the programs they own. ${ }^{24}$ Independent television station operators, who compete against cable stations that rebroadcast distant signals of other independent stations, are paid a fee by advertisers for commercial time on a given program based on the number of viewers who watch the program and its advertising. ${ }^{25}$ When cable through rebroadcasting duplicates programs shown on local independent television, fewer viewers watch those programs on the local independent. ${ }^{28}$ Independent stations thus lose advertising revenue and correspondingly pay less for syndicated programming. ${ }^{27}$ The resulting loss to copyright owners is not made up by cable's royalty payments to these owners because, under the 1976 Act, Congress fixes the copyright rate cable owners pay to rebroadcast the programs at an artificially low rate.

21. Rivkin, supra note 5, at 1480 ("TT]he purpose of distant signal importation is to enhance the salability of cable services by offering subscribers additional opportunities for popular programming beyond those available over the air.").

22. Chazen \& Ross, supra note 5, at 1838-39 ("Many of the advertisements carried over the distant signal are local in nature or are placed by a national advertiser but keyed to a regional market. The advertiser thus gains little when his messages are heard in some distant city which he did not select."); $c f$. National Cable Television Ass'n v. CRT, 724 F.2d 176, 189 (D.C. Cir. 1983) ("Our review of the record satisfies us that substantial evidence supports the Tribunal's findings . . . that television broadcasters are not compensated by advertisers for the additional distant audiences generated by cable retransmissions.").

23. Section $111(c)(3)$ prevents the substitution of advertising on rebroadcast distant signals. Such advertising is not permitted because "the placement of substitute advertising harms the local broadcaster in the distant market because the cable system is then competing for local advertising dollars without having comparable program costs." House Copyright Report, supra note 2, at 94, 1976 U.S. Cong. CODE \& AD. News at 5708.

If this Note's proposals were to be implemented, however, cable would pay market rates for programs equal to those paid by local broadcasters. The House Committee's objection to advertising substitution would be moot and substitution of advertising should then be permitted in order to allow cable to pay market rates for the programs they rebroadcast.

24. House Copyright Report, supra note 2, at 90, 1976 U.S. Cong. CoDE \& AD. NEws, at 5704-05; 1981 Senate Hearings, supra note 20, at 199 (testimony of Jack Valenti, President, MPAA); Copyright Law Revision: Hearings on H.R. 2223 before the Subcomm. on Courts, Civil Liberties, and the Administration of Justice of the House Comm. on the Judiciary, 94th Cong., 1st Sess., 736-37 (1975) (testimony of Jack Valenti, President, MPAA).

25. B. OWEN, J. BeEbe \& W. MANning, supra note 12, at 4; Botein, supra note 13, at 3.

26. See The Communications Act of 1978: Hearings on H.R. 13015 before the Subcomm. on Communications of the House Committee on Interstate and Foreign Commerce, 95th Cong., 2nd Sess. 279-80 (1978) (statement of Jack Valenti, President, MPAA) [hereinafter cited as 1978 House Hearings]; Meyer, The Feat of Houdini or How the New Act Disentangles the CATV-Copyright Knot, 22 N.Y.L. SCH. L. REv. 545, 546.

27. See, e.g., Meyer, supra note 26, at 546; New Cable Regs Rile Up Syndies, VARIETY, Aug. 20, 1980, at 1 (broadcasters are paying less for syndicated programming as a result of cable rebroadcasting). 


\section{Copyright Liability}

A range of aggregate losses to copyright owners due to cable rebroadcasting may be calculated using empirical estimates of the value of cable rebroadcasting to cable viewers. These estimates of the value of four distant signals' programs to cable viewers range from 72 cents per month to $\$ 2.90$ per month per subscriber. ${ }^{28}$ As of December 1983, there were more than 34 million cable subscribers nationwide. ${ }^{29}$ Thus, although cable copyright payments totaled some $\$ 69.2$ million in $1983,{ }^{\text {so }}$ the total loss to copyright owners from compulsory licensing could total from $\$ 241$ million to $\$ 1.11$ billion per year. ${ }^{31}$ This represents a potential loss of more than one-third of television-producer revenues in that year. ${ }^{32}$

The losses due to cable rebroadcasting reduce program diversity in two ways. One reduction results from the diminished value of television programs to copyright owners caused by cable rebroadcasting. Because the aggregate value of television programs is hundreds of millions of dollars lower every year than it would be without cable rebroadcasting, television producers are likely to produce far fewer programs in the future than they otherwise would.$^{33}$ Cable rebroadcasting also reduces program diversity because cable's rebroadcast of existing syndicated programs is heavily subsidized under the Act's provisions. ${ }^{34}$ This subsidy allows cable to rebroad-

28. Besen, Manning \& Mitchell, supra note 4, at 89 .

29. 1984 Broadcasting/Cablecasting Yearbook D-3. As of the same date, there were 5,800 operating cable systems in the U.S. with another 1,939 franchises approved but not built. Id.

30. Parties prepare for copyright battleground, Broadcasting, Nov. 19, 1984, at 62.

31. $\$ .76 \times 12 \times 34,000,000-\$ 69,200,000=\$ 241,000,000 . \$ 2.90 \times 12 \times 34,000,000$ $\$ 69,200,000=\$ 1,110,000,000$. These figures represent the range of marginal revenue viewers would pay to see distant signals rebroadcast on cable television. If program producers are rational actors, they will seek to maximize their profits by producing television programs to the point where the marginal cost of their programs equals the marginal revenue viewers will pay to view these programs. The potential utility to cable viewers from programming that would have been available to them absent the inefficiencies of the current law thus suggests a range of uncaptured value and revenues to copyright owners which is lost to them due to the artificially-low rates contained in the current law. See also 1978 House Hearings, supra note 26, at 279 (statement of Jack Valenti, President, MPAA) (as of 1981, cable paid "1.1 percent, on the average, of its total revenues for all the programming it receive[d], while the [average] local broadcaster pa[id] . . . 25 to 30 percent of its revenues for those program expenses"); B. OWEN, J. BEEBE \& W. MANNING, supro note 12, at 145 (making an aggregate welfare calculation similar to that above and estimating a similar magnitude of loss). Cable revenues from 1978 through 1982 totaled $\$ 14.1$ billion. Hatfield \& Garrett, supra note 3, at 437 n.16. Compulsory licensing fees paid during this period were only $\$ 91.5$ million. $I d$.

32. No published figures of copyright owner income are available to the public. Fritz Attaway, general counsel of the Motion Picture Association of America, a lobbying organization representing the owners of a substantial amount of all U.S. syndicated programming, estimates that U.S. copyright royalties from sales to television amounted to $\$ 2.3$ billion in 1983 . Telephone interview with Fritz Attaway, General Counsel, MPAA (February 21, 1985).

33. See R. Nol,, M. PECK \& J. MCGowan, supra note 12, at 63-65, 69-70 (explaining how the supply of syndicated programming adjusts as a result of changes in the price paid for programming); Besen, Manning \& Mitchell, supra note 4, at 68.

34. Under the current law, cable pays far less than market value to rebroadcast syndicated television programs. See supra text accompanying notes $28-32$. This creates a subsidy from copyright owners to cable operators. 
cast existing programs for bargain rates and thus sharply diminishes cable's incentive to produce new programs. ${ }^{35}$

Optimal program diversity will result if cable operators and the public they serve pay to copyright owners the marginal value derived from viewing syndicated programming. Assuming a competitive market, this amount would be the market price for copyrighted programming. If cable were to pay this market price, rather than the artificially low price it currently pays, economic efficiency would also result. ${ }^{38}$ Thus, the artifically low statutory copyright rates frustrate the fundamental goals of government regulation of the cable industry.

\section{G. The Perils of Deregulation}

Many commentators on the cable industry have argued that Congress should deregulate cable rebroadcasting. This would allow cable operators and copyright owners privately to negotiate market rates for cable rebroadcasting, ${ }^{37}$ and theoretically would increase program diversity as a result. ${ }^{38}$ Congress rejected deregulation in 1976, however, because cable rebroadcasting was fully deregulated from 1968 to 1972 and the deregulation resulted in a complete "freeze" on all cable rebroadcasting. ${ }^{39}$ During the four-year period that deregulation was in effect, only one cable station in the country was able successfully to negotiate even limited rebroadcast of syndicated television programs. ${ }^{40}$

Congress saw two potential reasons for the freeze. One reason was that television broadcasters were very hostile toward the development of cable television. ${ }^{11}$ Since program producers and owners sell the overwhelming majority of their programs to networks and independent broadcasters, ${ }^{42}$

35. See 1978 House Hearings, supra note 26, at 279 (statement of Jack Valenti, President, MPAA); Hatfield \& Garrett, supra note 3, at 474.

36. Besen, Manning \& Mitchell, supra note 4, at 68, 83. See R. LIPSEY, P. STEINER \& D. PURvis, supra note 4, at 231-232 (efficiency requires payment of market prices); P. WONNACOTr \& R. WonNACOTT, supra note 4, at 494-98 (same). See also supra note 4 on the advantages of an efficient distribution of goods.

37. See H.R. 3844, 97th Cong., 1st Sess., introduced on June 8, 1981 by Rep. Barney Frank (providing for full copyright liability), discussed in More on copyright from register Ladd, BROADCASTING, July 27, 1981, at 99; Besen, Manning \& Mitchell, supra note 4, at 79-82; Note, supra note 13 , at $633-38$.

38. Besen, Manning \& Mitchell, supra note 4, at 95.

39. See Malrite T.V. of N.Y. v. FCC, 652 F.2d 1140, 1148, n.9 (2d Cir. 1981); Botein, supra note 13 , at 3 .

40. Botein, supra note 13 , at 3.

41. See Greene, supra note 12, at 275 (terming cable and broadcasters "bitter enemies"); Rivkin, supra note 5, at 1477-78 (describing television's economic reasons to thwart cable's development, and concluding "[i]t should come as no surprise, therefore, that cable television's older siblings should try to throttle the infant in its crib").

42. Chazen \& Ross, supra note 5, at 1830 . According to the general counsel of the Motion Picture Association of America, a trade organization that represents the largest program producers, sales to cable are negligible. Virtually all revenues from sales of copyrighted programs come from networks, 
program owners had strong incentives to support broadcasters against cable by withholding their consent to cable rebroadcasting of copyrighted programs. ${ }^{43}$ Networks have also taken advantage of their relationship with independent network affiliates in their efforts to thwart cable's development. ${ }^{44}$ Some commentators have argued that active enforcement of the antitrust laws would minimize anticompetitive behavior by broadcasters. ${ }^{45}$ Such laws are likely to be ineffective, however, because improper conduct sufficient to trigger the antitrust laws is often well hidden and both difficult and expensive to prove. ${ }^{48}$

Congress was also concerned that the transaction costs of negotiating rebroadcasting consent would be prohibitive. ${ }^{47}$ Congress consequently passed the current copyright law, which guarantees cable the right to rebroadcast all programs shown on television, thus preventing another

independent television stations, and pay cable services. Telephone interview with Fritz Attaway, supra note 32.

43. 1981 Senate Hearings, supra note 20, at 32 (testimony of Barbara Ringer, former Register of Copyrights) ("I think this point [broadcaster attempts to choke off cable's growth by denial of programming] was very much in Congress['] mind, although it never really came out too openly . . . . Broadcasting will use what economic weapons it can [to distroy cable]."); id., at 41-42 ("Because the competitive threat of cable to the broadcasting industry is so real, the likelihood of refusals to license cable systems at any price is also very real."); see Chazen \& Ross, supra note 5, at 1833-34; B. OWEN, J. BEEBE \& W. MANNIng, supra note 12, at 21 (discussing "friendships" between networks and the major copyright owners); id. at 29 (discussing weakness of copyright owners' economic power, particulary in contrast to that of networks); of. Greene, supra note 12, at 275 ("Because broadcasters and cable systems were bitter enemies, it was extremely unlikely that [rebroadcast] consent would ever be granted.").

44. One recent example of network efforts to prevent cable's development is a memo sent by ABC to its network affiliates, discussed in Shaking Up the Networks, TrME, Aug. 9, 1982, at 54. The memo encourages all $A B C$ affiliates to "use every resource, including the stations' news and public affairs departments, to campaign [against cable and] for "free TV."

45. See On The Cable: The Television of abundance, Report of the Slonn Commission on Cable Communications 54 (1971).

46. R. Noll, M. Peck \& J. MCGowan, supra note 12, at 178 n.35. See generally K. ElziNGa \& W. Bretr, The AnttTrust Penalties: A Study in LaW and Economics 40-43, 54-62 (1976) (discussing ineffectiveness of antitrust laws in checking anticompetitive activity); R. SHERMAN, OLIGOPOLY: AN EMPIRICAL APPROACH (1972) ("Antitrust policy is most effective against well-defined collusive practices, such as price fixing, but it has been almost helpless against cases of possible tacit collusion by a few firms in concentrated industries, and it has failed altogether to deal with perverse aspects of entirely independent behavior by firms that enjoy large shares of their markets."). Also, many types of anticompetitive action against cable are exempt from the antitrust laws. For example, the actions discussed in ABC's memo to its affiliates, see supra note 44, are probably protected from the antitrust laws under the First Amendment. See 16E J. von Kalinowski, Business Organizations: ANTtTRUST LAWS AND TRAde Regulation § 45.08 (1985).

47. House Copyright Report, supra note 2, at 89, 1976 U.S. Code Cong. \& AD. NEws 5659, 5704; id. at 362, 1976 U.S. CODE Cong. \& AD. News 5659, 5804 (concurring views of Rep. Danielson). 
freeze, ${ }^{48}$ as well as establishes statutory copyright rates in order to assess some measure of copyright liability for cable rebroadcasting. ${ }^{49}$

\section{A NEW PROPOSAL}

\section{A. The Need for Negotiations}

Negotiated adjustments of the statutory copyright royalties between cable and copyright owners would promote Congress' goal of greater program diversity and efficiency in the production of television programs. ${ }^{.0}$ Assuming a market in which both cable and copyright owners could calculate the royalties paid by cable for the right to rebroadcast a given program, ${ }^{\text {s1 }}$ cable and copyright owners would have the economic incentive to negotiate a market price for cable rebroadcasting. ${ }^{62}$ In those instances where the statutory rate is higher than the marginal cost of rebroadcasting, copyright owners will maximize their personal wealth by reducing the royalty they charge cable to rebroadcast their programs in order to ensure that their programs are rebroadcast more frequently compared to more expensive programs. ${ }^{53}$ For those programs where the marginal cost

48. See Note, supra note 10 , at 950 ("To presume a free marketplace in the absence of compulsory licensing ignores the reality of the communications industry."); see also Copyright Issues: Cable Television and Performance Rights, Hearings before the Subcomm. on Courts, Civil Liberties, and the Administration of Justice of the House Comm. on the Judiciary; 96th Cong., 1st Sess. 21 (1979) (statement of Barbara Ringer, Register of Copyrights) (loss of cable's compulsory license "would, we think, produce massive retransmission denials rather than consents"); Note, Copyright Owners vs. Cable Television: The Evolution of a Copyright Liability Conflict, 33 Syracuse L. Rev. 693, 723 (1982) (compulsory license prevents broadcaster-inspired cutoff of programming).

49. See House Copyright Report, supra note 2, at 89, 1976 U.S. CoDE Cong. \& AD. NEws, at 5704 ("IT] ]he Committee believes that cable systems are commercial enterprises whose basic retransmission operations are based on the carriage of copyrighted program material and that copyright royalties should be paid by cable operators to the creators of such programs.").

50. See Besen, Manning \& Mitchell, supra note 4, at 68,86 .

51. But see supra text accompanying notes 18-19 (showing that this assumption is not valid under the current law).

52. Both sides will negotiate to the point where the marginal revenue paid by cable in royalties equals the marginal cost of rebroadcast programs. The marginal cost to the copyright owner of rebroadcasting a program equals the loss of syndication revenues from local independents and cable stations who also broadcast the program in the relevant market and whose advertising revenues are reduced by cable's rebroadcasting. Copyright owners' marginal revenue from rebroadcasting is the amount they receive in royalties from cable.

Cable's marginal cost (net of operating costs) is the copyright royalty it pays on each program, which it negotiates depending on the marginal revenue it derives from the rebroadcast of each program. This revenue comes from two sources: 1) the advertising revenue from commercial spots cable sells to accompany the program, see supra note 23 , and 2) the program's proportionate contribution to monthly cable subscription revenues. Calculation of each program's share of subscription revenues may not be exact in many instances, although close approximations likely may be made by estimating the marginal subscription revenues contributed by each distant signal rebroadcast and then dividing that value up among the programs carried on that distant signal.

53. See generally R. LIPSEY, P. STEINER \& D. PuRvis, supra note 4, at 73-74 (discussing movement of prices to equilibrium, the point of optimal efficiency); P. SAMUELSON, supra note 4, at 57-58 (same); P. Wonnacotr \& R. Wonnacotr, supra note 4, at 46-49 (same). 


\section{Copyright Liability}

of rebroadcasting is greater than the statutory rate, the Coase Theorem ${ }^{54}$ shows that copyright owners will be willing in effect to bribe cable not to rebroadcast their programs, thus preserving the market value of their programming. ${ }^{55}$ The resulting increase in copyright royalties for rebroadcasting to an efficient, market level will maximize program diversity. ${ }^{\text {s6 }}$

Although the transaction costs of negotiations may prevent some of these efficiency-enhancing adjustments, ${ }^{57}$ such costs are likely to be lim-

54. Coase, supra note 8 , at $1-44$.

55. Besen, Manning \& Mitchell, supra note 4, at 79-81. Efficiency will also be enhanced despite transactions costs of such adjustments, although not to the same level possible without thein. See infra note 77.

Society may object to the distributional effects of such payments, however. Cable regulators might prefer instead to exempt a portion of copyright owners' most valuable television programs from cable's compulsory license. In order to rebroadcast these exempted programs, cable would be forced to pay a market-level royalty to copyright owners, rather than forcing copyright owners to pay to prevent the rebroadcast of such programs. One experiment in identifying and protecting a handful of the most valuable syndicated programs was the FCC's syndicated program exclusivity rules, which were in effect between 1972 and 1980. Reimposition of the exclusivity rules would eliminate the need for transfer payments from copyright owners to cable operators in order to prevent rebroadcast of programs covered by the rules. For a full discussion of the exclusivity rules, see Besen, The Economics of the Cable Television Consensus, 17 J.L. \& Econ. 39, 43-47 (1974).

Another way to limit such payments is to limit the permissible substitution of programs on a distant signal. Without limits on substitution of programs, a cable owner could select all the most expensive programs in the country and splice them into one distant signal, while paying only the compulsory, average distant signal rate for this new super signal. Although the Coase Theorem demonstrates that an efficient level of rebroadcasting would still result through the payment of bribes by copyright owners, the cost of such bribes might unfairly injure owners of expensive copyrighted programs. By limiting the substitution of programs without the permission of copyright owners, no one distant signal would show more than a limited number of the most expensive programs nor receive an unacceptable amount of side payments from copyright owners.

Finally, there will be some limitation on the payments cable may demand not to rebroadcast a given program, since if the demand for payments gets too high, a supplier may always simply take the program off the air. Since cable benefits from rebroadcasting the most valuable television programs, both sides will have incentives to bargain the amount of the transfer down to a market-approximating rate.

56. For all copyright rates below market level, rebroadcasting will be subsidized and thus will crowd out new programs. Rates above the market level will discourage cable rebroadcasting, thus reducing the syndication value and future production of television programs. At a market level of copyright royalties, however, the quantity of programs produced will be maximized. This market level, where the price of cable rebroadcasting equals its marginal cost, is by definition the level where existing programs are most efficiently broadcast. See supra note 4. Thus maximal program diversity ensures optimal efficiency. Cf. B. OWEN, J. BeEBE \& W. MANNING, supra note 12, at 12 ("IInefficiency] is a failure to produce the type and quantity of output that would maximize consumer welfare [optimal diversity].").

The market level of copyright royalties will maximize both types of diversity, optimal production of new programs and optimal use of existing ones. This adjustment will occur initially with existing programs. As royalties for rebroadcasting (i.e. the marginal revenue to copyright owners) adjust to a market level and restrictions on program substitution are eliminated, existing programs will be rebroadcast increasingly to the point where the marginal cost of rebroadcasting additional programs equals the new revenues. To the extent, however, that new programs generate larger audiences and greater revenues than reruns of existing programs at equal aggregate cost, such new programs will be produced and broadcast instead of existing programming until the aggregate marginal cost of all cable's additional programming equals the new marginal revenue.

57. See infra note 77. 
ited. ${ }^{58}$ Substantial adjustments of copyright royalties to market levels are thus likely to occur. ${ }^{58}$ Negotiated adjustments between cable and copyright owners are not possible under current copyright law, however, because copyright owners are precluded from determining the royalties paid to them per program. ${ }^{80}$

\section{B. A New Method of Calculating Royalty Rates}

Diversity-enhancing copyright negotiations between copyright owners and cable operators will occur only if both parties can easily determine royalty rates under cable's compulsory license prior to any given program's rebroadcast. Although any easily-determined copyright rate will facilitate negotiations and program diversity, an initial, marketapproximating statutory royalty rate will reduce the amount of rebroadcasting negotiations necessary to reach the market rate for many pro-

58. See Besen, Manning \& Mitchell, supra note 4, at 87 . Cable has already negotiated contracts for first-run programs and has been unimpeded by prohibitive transactions costs. See, e.g., Oversight of the Copyright Office and the Copyright Royalty Tribunal: Hearing Before the Subcomm. on Patents, Copyrights and Trademarks of the Senate Comm. on the Judiciary, 98th Cong., 1st Sess. 22 (1983) (statement of D. Ladd, Register of Copyrights) (discussing success of cable stations such as CNN, ESPN, and HBO despite full copyright liability) [hereinafter cited as 1983 Senate Hearings]; Taafe, He Spent a Lot to Save a Lot More, SPORTs Illustrated, Feb. 11, 1985, at 168 (discussing high bidding between cable sports channels for baseball and football broadcast rights). The concentration of cable ownership among a handful of multiple station operators strongly suggests that the transactions costs of royalty negotiations will be slight. See 1981 Senate Hearings, supra note 20, at 5 (statement of D. Ladd, Register of Copyrights) (discussing growing concentration and power of cable companies, giving "cable access to capital, management skill, and bargaining power which allows cable more effectively to compete and bargain for program materials"). In 1983, 20 companies provided service to almost $50 \%$ of cable subscribers. The top 50 companies served $65 \%$ of the market. 1984 Broadcasting/Cablecasting Yearbook D-320. Furthermore, if efficient, cable operators could form an ASCAP-like group to negotiate blanket rates. See 1981 Senate Hearings, supra note 20, at 87 (statement of Dale Hatfield, Acting Assistant Secretary, National Telecommunications and Information Administration, U.S. Dep't of Commerce). Such an organization already exists for copyright owners. The Motion Picture Association of America has a membership of 9 major originators and producers of television programs and films. The group currently divides $70-75 \%$ of all royalties collected by the CRT among its members, see Christian Broadcasting Network v. CRT, 720 F.2d 1295, 1301 (D.C. Cir. 1983), National Ass'n of Broadcasters v. CRT, 675 F.2d 367, 372 (D.C. Cir. 1982), and could easily develop a unified negotiating arrangement for cable copyright royalties. The development of "middlemen," entrepreneurs eager to facilitate copyright royalty negotiations in exchange for a percentage of the savings, will also reduce the level of such costs to cable and copyright owners. See 1981 Senate Hearings, supra note 20, at 45 (testimony of Henry Geller); Note, supra note 48 , at $724,727-28$.

59. Some authorities suggest that the public policy behind the Copyright Act encourages such negotiations. See, e.g., 1983 Senate Hearings, supra note 58, at 63 (statement of Edward "Eddie" Ray, Chairman, CRT) ("The Copyright Act does not make illegal private licensing arrangements between copyright owners and cable operators. In accordance with the public policy purposes reflected in the Copyright Act, the Tribunal in all its proceedings welcomes and encourages voluntary agreements."). The current system, however, prevents such agreements. See supra notes 17-20 and accompanying text.

60. Because copyright owners are unable to calculate the royalties they will receive for their programs under the current law, they are unable to determine whether new, negotiated rates will be in their interest and what any new rates should be. 
grams, ${ }^{61}$ and thus will reduce the aggregate transaction costs of these negotiations. ${ }^{62}$ It will also reduce the distortion caused by non-market rates in those instances where transaction costs prevent negotiated adjustment of the statutory royalty rate. ${ }^{63}$ This Note therefore proposes the establishment of a program-by-program copyright royalty rate that would allocate an increased statutory rate per distant signal ${ }^{64}$ to each program rebroadcast by a cable operator in proportion to its relative market value ${ }^{65}$ compared to the market values of other programs shown as part of the distant signal.

Every month, program copyright owners would have an incentive to publish the average market price paid by television stations during the previous month per thousand viewers for each of the owners' programs. ${ }^{68}$ Every three months, cable operators would separately total these figures for all programs shown on each distant signal rebroadcast and divide the new statutory percentage of revenues per signal among the programs shown in proportion to each program's share of the aggregate market value of the distant signal's programs. ${ }^{67}$ Cable operators would then send

61. This is because for many transactions, no negotiated adjustments will be necessary.

62. The lower these transactions costs, the greater the revenues copyright owners will receive for their programs. The value of syndicated programs will thus be increased and more programs will be produced as a result.

63. If negotiations are not possible, the new, market-approximating rate will reduce the levels of subsidy from copyright owners to cable operators and the attendant losses in program diversity caused by the subsidy.

64. The current rate of less than $1 \%$ of cable revenues as royalty for most distant signals is clearly less than the market value of such signals. See supra text accompanying notes 28-31. Alternatively, many have charged that the new marginal rate of $3.75 \%$ set by the CRT for distant signals beyond a certain number is far too high. See National Cable Television Ass'n v. CRT, 724 F.2d 176, 181-89 (D.C. Cir. 1983). This Note proposes, as a compromise, that the copyright rate for distant signals be adjusted to a flat $2.5 \%$ royalty per distant signal rebroadcast. Estimates by the CRT show that a royalty rate of $3.75 \%$ per signal results in a cost of approximately 35 cents per signal per month per subscriber. 1983 Senate Hearings, supra note 58, at 64 (statement of Edward "Eddie" Ray, Chairman, CRT). The rate proposed in this Note would thus be less than 25 cents per signal per month per subscriber. By comparison, average revenues per subscriber for cable are $\$ 20$ per month. Critiqu ing Cable's Future, Brondcasting, Dec. 10, 1984, at 32. A more scientific determination of a proper flat rate, however, might be constructed using models similar to those used by $R$. Noll, $M$. Peck \& J. McGowan, supra note 12 , at $277-88$, or by R. PARK, Audience Diversion Due to Gable Television: A Statistical Analysis of New Data, The Rand Corp., January, 1979, reprinted in Inquiry Into the Economic Relationship Between Television Broadcasting and Cable Television, 71 F.C.C.2d 632, 716-60 (1979).

65. Relative market value would equal the program's average market value divided by the aggregate market values of all programs shown on the distant signal.

66. Congress currently has no authority to require copyright owners to make this information available, although it could predicate a significant amount of copyright owners' receipt of the new, higher royalties on release of this information. See infra note 68. Francis Vincent, President of Columbia Pictures, a major copyright owner, has said that he would expect fellow copyright owners to join him in making such information available if it were done in exchange for higher copyright royalties. Interview with Francis Vincent, President, Columbia Pictures, February 26, 1985.

67. For example, assume that cable company CABLE pays $2.5 \%$ of its subscription revenues $(\$ 10,000)$ each year under the current law to the CRT in order to rebroadcast distant signals KTTV. If KTTV broadcasts only three programs, Star Trek, $M^{*} A^{*} S^{*} H$, and Hogan's Heroes, all year in 
royalty checks for the proper amount directly to copyright owners. Under this proposal, royalties could be calculated without regulatory intervention and expense, ${ }^{68}$ while transaction costs would be minimized by the new, market-approximating initial royalty rates. ${ }^{69}$

equal hourly amounts, and the average market value of Star Trek is $\$ 400$ per hour, $M^{*} A^{*} S * H \$ 300$ per hour, and Hogan's Heroes $\$ 300$ per hour, CABLE would send checks for $\$ 4,000, \$ 3,000$ and $\$ 3,000$ to each of the copyright owners of each of the programs, respectively, every year. All parties would be able accurately to calculate the royalties due on each program in advance and thus to "finetune" these rates or the programs they show to maximize their viewers' enjoyment of cable as well as their own profits.

If, in this example, the marginal cost of CABLE's rebroadcast of Star Trek was only $\$ 2,000$ per year, CABLE and Star Trek's owners would both have incentives to reduce the royalty paid to equal the market rate of $\$ 2,000$. If the copyright owner did not reduce the rate, CABLE might substitute a cheaper program for Star Trek in order to save money. Because the copyright owner benefits from any royalty payment equal to or greater than the cost of rebroadcasting the program, he will encourage CABLE to rebroadcast his program in additional hourly programming slots by negotiating a reduction in the royalty rate for the program. If the resulting negotiated rate is $\$ 2,000$, CABLE's new annual royalties will be only $\$ 8,000$. If, on the other hand, the marginal cost of rebroadcasting Hogan's Heroes is $\$ 3,500$ per year, the owner of Hogan's Heroes will have an incentive to encourage CABLE not to rebroadcast Hogan's Heroes and will pay CABLE up to $\$ 500$, if necessary, in order to prevent the program's rebroadcast. (CABLE could substitute more Star Trek episodes in place of Hogan's Heroes.) Alternatively, if some form of syndicated exclusivity protection is reinstated, see supra note 55, CABLE must either pay the owner an additional $\$ 500$ to rebroadcast the program or substitute some other program in its place. The burden of obtaining the right to show this program would be on the cable station rather than on the copyright owner. Programs included under such protection should be limited by regulation, however, in order to prevent the protection's use as an anticompetitive weapon by broadcasters.

This proposal assumes that the value of programs in relation to one another in individual television markets is the same as their proportional value in the national syndication market. Interviews with copyright owners confirm that syndicated programs maintain equivalent value in relation to their competitors in virtually all markets throughout the country. Also, even if the proportionate value of programming varies in some markets, the use of national average values in calculating initial royalty rates will not be inefficient since the initial rates will be adjusted through negotiations between cable operators and copyright owners to accurate, market-specific levels.

68. Enforcement of the new copyright system would be far simpler and less expensive than enforcement of the current law. Copyright owners would have an economic incentive to make available to the U.S. Copyright Office on a monthly basis the average price per hour of each of the programs they syndicate based on all syndication contracts in force for that program throughout the country. Those programs for which no information is provided could be rebroadcast by cable upon payment of a token fee of, say, $50 \notin$ per hour rebroadcast in lieu of a full royalty. Copyright owners who make monthly figures available to the Copyright Office would be obliged to agree to make all contracts with broadcasters for broadcast of their syndicated programs available for in camera inspection by an official of the Copyright Office upon request. Criminal or civil penalties could be developed for fraudulent reporting of the average market value of syndicated programs for copyright royalty calculation purposes.

Private civil suits would be the fundamental means of enforcement of the new law in the event of non-payment by a cable owner. Potential punitive damage awards would enhance the deterrent nature of such suits. The Copyright Office could examine the syndication contracts between copyright owners and broadcasters, both at random and in response to complaints by cable operators and other copyright owners, in order to ensure that the average market values submitted by copyright owners are accurate. In general, however, the simplicity of the system, combined with the deterrent effect of private actions and limited government review, would prevent abuse of the new system at minimal cost.

69. The more accurate the initial royalty rate, the greater the number of cases where no negotiated adjustments will be necessary.

This Note proposes a proportionate royalty limited to $2.5 \%$ of the cable system's gross subscription revenues per distant signal rebroadcast rather than straight payment by cable to copyright owners of 


\section{Comparative Advantages of the New Proposal}

This new plan seems superior to both current cable copyright law and deregulation of cable rebroadcasting in promoting Congress' goals of program diversity and economic efficiency. Assuming the absence of a broadcaster freeze and minimal transaction costs, ${ }^{70}$ mutual self-interest and transfer payments from copyright owners to cable operators will induce negotiation of a market price and produce an optimal level of cable rebroadcasting. ${ }^{71}$ This new plan will ensure efficiency in the same way deregulation theoretically would, but with added protection against a second freeze on cable rebroadcasting.

In the event of anticompetitive pressure on copyright owners to withhold access to television programs from cable, deregulation would result in an end to all cable rebroadcasting. ${ }^{72}$ Under the new plan, however, cable would have access to rebroadcast all syndicated television programs for market-approximating copyright rates. The new plan would also promote the collapse of any freeze by facilitating "cheating" on a broadcastersupported freeze. A freeze on cable rebroadcasting benefits only television broadcasters: It injures both cable and copyright owners. ${ }^{73}$ Nevertheless,

each program's published market value in order to allow cable more accurately to predict its costs from month to month. Because broadcasters and not cable operators control what is shown on rebroadcast signals, the proportionate royalty allows cable to anticipate its costs of rebroadcasting each month absent negotiations. Use of a per-station rate rather than payments based only on program market value will also allow comparisons between current rates and rates under the new proposal. Finally, some cable operators may, despite monitoring by the Copyright Office and civil and criminal penalties for inaccurate reporting of average copyright royalties for syndicated programming, fear any copyright system where the initial royalties paid for programming are determined solely on information supplied by copyright owners. This Note's proposed flat royalty fee per distant signal would assure cable owners who did not negotiate new royalty rates that the amount of their royalty payments would not be affected by the information released by copyright owners. Copyright owners would need, however, to monitor each other's published rates with the help of the Copyright Office in order to ensure that they receive a proper proportion of royalties absent royalty negotiations.

Congress might decide, however, that payment of a straight market value would be preferable to the limit of $2.5 \%$ of revenues per distant signal, absent negotiations. Despite the reasons for a proportionate royalty discussed above, payments based solely on average market value would be easier to calculate and would avoid the need to limit program substitution, since the limit on royalties to be paid for programs shown on one distant signal would no longer apply. See supra note 55. Full, marketapproximating royalties for all programs rebroadcast would be calculated and assessed.

70. These assumptions are relaxed below.

71. See supra text accompanying notes 52-56.

72. Such a freeze occurred from 1968 until 1972. See supra text accompanying notes 39-40. This termination of all cable rebroadcasting would mean substantial losses in program diversity due to the loss to viewers of programs that were previously available over cable, and to the reduction in the value of television programs equal to the value of market-level royalties for cable rebroadcasting. Indeed, some suggest that the end of cable rebroadcasting would result in the demise of cable television. See $\mathrm{R}$. Noll, M. PECK \& J. MCGowsN, supra note 12, at 161-62 (terming this an "inescapable conclusion"); see also 1983 Senate Hearings, supra note 58, at 22-23 (statement of D. Ladd, Register of Copyrights) ("[r]etransmitted broadcast signals . . . remain the mainstay of cable programming").

73. Cable is injured because it cannot rebroadcast those programs where the marginal revenue from rebroadcast exceeds the marginal cost of such rebroadcast. Copyright owners' revenues are also maximized by cable's rebroadcast of their programs up to an equilibrium level. The revenues of 
under deregulation, copyright owners will not negotiate with cable for fear of broadcaster retaliation. The new plan, in contrast with deregulation, would guarantee cable access to syndicated programs, while making copyright compensation a private matter between cable and copyright owners rather than a matter of public knowledge. ${ }^{74}$ Broadcasters would be unable to determine which copyright owners were negotiating adjustments in rebroadcasting royalty rates and would thus be unable to retaliate against owners who violated their freeze by negotiating reductions of copyright royalties with cable stations. The new proposal would therefore significantly decrease the likelihood of both the attempt and the success of any anticompetitive freeze.

The new plan is also superior to current law in the event of anticompetitive pressure. Even without negotiations, the new plan would impose royalty rates that are closer to market values than those under the current copyright framework..$^{75}$ In addition, the new plan would permit efficiency and diversity-enhancing negotiations between cable operators and those copyright owners who seek privately to resist anti-cable pressure by broadcasters. ${ }^{78}$

This Note's proposal will also be more efficient than both deregulation and the current law despite transaction costs of negotiations. Some negotiations costs are unavoidable and will reduce the efficiency and program diversity that would result from costless negotiations. ${ }^{77}$ The new plan will create greater program diversity than the present copyright system if transaction costs are not so high as to prohibit adjustment negotiations for

television broadcasters, on the other hand, decline if cable rebroadcasts in competition with broadcast television programming for local audiences. See supra note 4; supra text accompanying notes $24-26$.

74. Under deregulation, any agreement between broadcasters and copyright owners in violation of the freeze would be immediately obvious to all concerned, since those programs on which agreement had been reached would be the only ones rebroadcast by cable. The policing of any freeze under deregulation would thus be easy. Under the new proposal, however, the only parties who would have a right to know what a cable station paid for any program would be the cable station, the program's copyright owner, and the supervisory administrator at the Copyright Office. See supra note 68. All programs would continue to be rebroadcast by cable, either under compulsory license or by special agreement, and those policing a freeze would be unable to determine which programs were rebroadcast under negotiated agreement and which were not.

75. Market-approximating rates result in efficient and optimally diverse programming levels. See supra note 56.

76. Broadcasters will have no way to discover which copyright owners are negotiating reductions in the statutory royalty fees and thus to retaliate against such owners. See supra note 74 . Because the compulsory license guarantees cable the right to rebroadcast distant signals, the rebroadcast of programs on any signal would not signify a violation of the freeze, as it would under deregulation.

77. See, e.g., J. Hirshleifer, Price Theory and Applications 237-43 (2d ed. 1980); H. KOHLER, INTERMEdiate Microeconomics: TheORY AND APPLICATIONS 32 (1982); W. Nicholson, Microeconomic Theory: Basic Principles and Extensions 372 (1985). Where gain from negotiations - the enhanced consumer or producer surplus or both resulting from adjusted copyright rates - exceeds the transactions costs, adjustments will occur despite such costs. Efficiency and diversity will be enhanced, but not as much as without transactions costs. Id. 
all television programs. ${ }^{78}$ Even if transaction costs are high enough to prevent all negotiations, however, the new plan will still facilitate greater diversity by adjusting the statutory copyright rates to approximate more closely those of a free market. ${ }^{29}$ The new plan also eliminates the cost of current litigation before the CRT, as well as the CRT's administrative costs. ${ }^{80}$

The new plan is also superior to deregulation of cable rebroadcasting if the transaction costs of negotiated adjustments prove to be prohibitive. Such costs would eliminate all cable rebroadcasting under deregulation, ${ }^{81}$ while the new plan would maintain cable rebroadcasting at marketapproximating copyright royalty rates, thereby increasing program diversity and efficiency.

\section{Political Acceptability}

The cable provisions of the 1976 Copyright Act essentially represent a compromise between program copyright owners and the cable industry. ${ }^{82}$ Thus any change must benefit both these constituencies in order to obtain congressional approval.

This Note's proposal will benefit program copyright owners by substituting market-approximating rates for the artificially low copyright rates that currently govern distant signal rebroadcasting. Copyright owners' revenues will increase substantially as a result. ${ }^{83}$

Cable operators will also benefit from the new proposal. Changes in current law consistent with this proposal will mean additional revenues for cable through new advertising and the opportunity to substitute pro-

78. Such costs are unlikely to be prohibitive. See supra note 58.

79. See supra text accompanying notes 33-36.

80. Such costs are substantial. See supra note 20. The former chairman of the CRT, Clarence L. James, Jr., wrote in his resignation letter in $\mathbf{1 9 8 1}$ that "anything short of elimination [of the CRT] is a blatant waste of taxpayers' money. . . .," quoted in Note, Cable Television: Toward an Improved Copyright and Communications Policy, 7 ART \& L. 239, 257 n.72 (1983). This proposal would not totally eliminate the functions of the CRT. The CRT would still be obliged to collect and distribute royalties collected from jukeboxes. 17 U.S.C. $\$ 116$ (b), (c) (1982). This function could undoubtedly be better handled by the Copyright Office, however, thus allowing the complete disbanding of the CRT.

81. Without the ability to negotiate the right to rebroadcast television programs, no rebroadcasting would occur.

82. See 1981 Senate Hearings, supra note 20, at 13 (statement of D. Ladd, Register of Copyrights) ("It [the 1976 Act] was adopted by Congress to implement an agreement reached between program syndicators and the cable industry."); Samuels, Copyright and the New Communications Technologies, 25 N.Y.L. ScH. L. REv. 905, 911 (1980) (calling Act's operative section a "legislative compromise between copyright and cable interests"); Note, supra note 80, at 242 ("[T] right Act was an attempt to balance the interplay between the relevant copyright and communications elements.").

83. This will occur through both the new, higher royalty rate absent negotiations, see supra note 64 , and the royalties above the new royalty rate that might be paid for programs protected under some new exclusivity rule. See supra note 55 . 
gramming within signals in order better to serve local markets. ${ }^{84}$ Mandating a new royalty rate $^{85}$ that is significantly greater than some current rates but less than others imposed as part of the GRT's review proceedings $^{88}$ may prove an acceptable compromise rate for all distant signals. Finally, because the proposal provides cable with a guaranteed level of programming in the event of anticompetitive efforts by broadcasters, it protects cable against another programming "freeze". ${ }^{87}$ Therefore, from a political standpoint, the new plan seems consistent with the compromise solutions which typify prior regulation of cable.

\section{CoNCLUSION}

This Note's proposal would promote greater program diversity and efficiency than either the current law or deregulation of cable rebroadcasting. The new plan retains cable's current compulsory access to distant signals and thus, in contrast to deregulation, should prevent a second freeze on cable rebroadcasting. The new plan also incorporates the efficiencyproducing negotiations that deregulation would provide. The introduction of these negotiations into the calculation of copyright royalty rates will efficiently develop a greater number and variety of television programs than will current law, thus realizing government policy goals for cable television.

-Stephen Hopkins Willard

84. See supra notes $15,23$.

85. See supra note 64 .

86. See supra note 15.

87. In contrast, the present law maintains the current subsidy to cable, thus injuring copyright owners without compensation, while deregulation would deny cable protection from another programming freeze. 